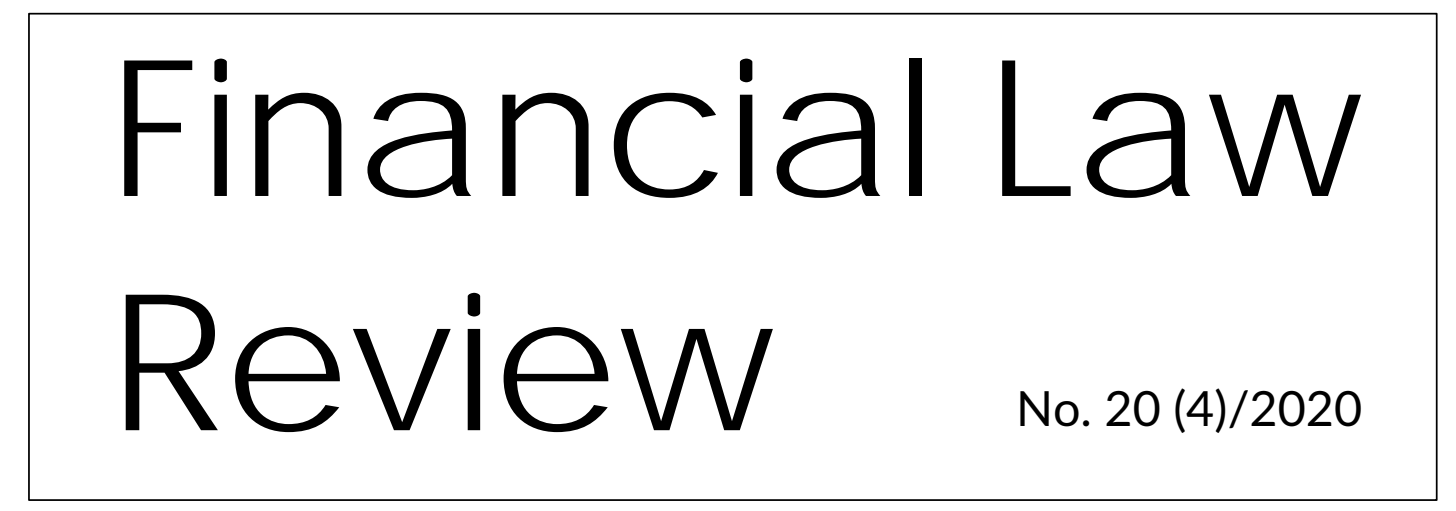

UNIVERSITY OF GDAŃSK • MASARYK UNIVERSITY • PAVEL JOZEF ŠAFÁRIK UNIVERSITY • UNIVERSITY OF VORONEZH http://www.ejoumals.eu/FLR

\title{
HOW BIG ARE LABOUR PRODUCTIVITY DISPARITIES IN POLAND?
}

\begin{abstract}
The ongoing discussion on inequalities in Poland focuses on household income. It ignores the scale of differences in labour productivity. In order to fill this gap, having combined national accounts and employment data we show that a narrow group of 7.2 million people working in non-financial and financial enterprises account for almost $60 \%$ of Polish GDP and $75 \%$ of income tax revenues and social security contributions from the private sector. This structure of the economy represents both
\end{abstract}

\footnotetext{
* PhD, Head of International Comparative Studies Department, Collegium of Economic Analysis, Warsaw School of Economics. He conducted research focused on the application of advanced econometric tools for assessment of economic policies' impact. Published in prestigious international journals like "Journal of Economic Geography", "Economic Modelling", "Applied Economics", "Fiscal Studies", "Economics", "German Economic Review", "Singapore Economic Review" or "Kyklos". Contact email: pcizko@sgh.waw.pl.

** PhD, Chief Economist, Civil Development Forum (FOR), Poland. Author specializes in long-term economic growth and structural changes. He is the author of multiple policy papers and analysis prepared for FOR, Ministry of Regional Development, the Lisbon Council, the Institute for Research in Economics and Fiscal Issues (IREF), the World Bank and others. Contact email: aleksander.laszek@for.org.pl.

*** PhD, Associate Professor at International Comparative Studies Department, Collegium of Economic Analysis, Warsaw School of Economics. He conducted research into economic growth, monetary policy, fiscal policy (taxes, sovereign debt), and labour market, focused on topics important for policy making and published, inter alia, in "Journal of Economic Geography", "Economic Modelling", "Kyklos", "Applied Economics", "Fiscal Studies", "Economics", "German Economic Review", "Singapore Economic Review". Contact email: arzonc@sgh.waw.pl.
} 
an opportunity and a threat to growth prospects. Flows of new employees to the enterprise sector from micro-businesses of low productivity or agriculture can considerably increase their productivity. At the same time, however, large differences in productivity, leading to income disparities, create the temptation to tax productive entities more heavily in order to finance transfers to less productive ones, which in turn perpetuates the current structure of the economy.

Key words: Taxes, productivity, institutional sectors, shadow economy.

JEL Classification: E24, H22, L53, O17, P42

\section{Introduction}

The ongoing discussion on inequality in Poland focuses primarily on income inequalities. It often ignores the issue of differences in labour productivity. While earlier studies [Brzeziński 2017] have pointed to relatively small income inequalities in Poland, the more recent ones [Brzeziński et. al. 2019], which supplement data from household surveys with tax data, indicate their much larger scale. Still, however, the analysis concerns the differences in income levels, rather than their sources. Such an approach results from the available data, which most often contain information on gross and net income of people or households, without the information on the value added generated by them. As a result, the discussion focuses on the amount of tax burden or possibly the distribution of income between the employer and employee. In both cases, the structure of added value and labour productivity is treated as given.

We propose an alternative approach, similarly as in Łaszek and Trzeciakowski (2018), taking as a starting point the value added generated by one employed person, without looking at how it is then shared between the employee and the capital owner. Data on labour productivity, i.e. value added per persons employed, is directly available for the enterprise sector, but it refers to less than 10 out of over 16 million people employed in the Polish economy. Moreover, data for the enterprise sector is not fully comparable with data from national accounts, which includes in particular the estimates of the shadow economy. In this article we show how to combine employment data with national accounts and, on this basis, estimate labour productivity and tax burden in key sectors of the Polish economy.

Apart from the study by Łaszek and Trzeciakowski (2018), we do not know any paper in which this problem would be analysed. Compared to that study, we use more sources and more up-to-date data. 
The article has the following structure. In the first part we describe how to combine value added data from national accounts with employment data. In the second part we discuss the structure of value added creation in the Polish economy obtained in this way. In the third part we discuss possible factors behind concentration of value added creation in Poland compared to other EU countries. In the fourth part we complement this picture with information on fiscal burdens. The last part of the article contains conclusions and directions of further research.

\section{Assigning value added to employees}

Assigning value added to people working in different sectors of the Polish economy requires combining data from national accounts with data on the labour market and enterprise sector and a number of corrections. The main data sources are national accounts by institutional sector for 2017 [GUS 2019] and data on the activity of nonfinancial enterprises for 2017 [GUS 2018].

\subsection{Non-financial enterprises}

The largest part of the value added is generated in the sector of non-financial enterprises (PLN 906.6 billion). According to Polish statistical office - Statistics Poland (former Central Statistical Office - GUS), less than 9.9 million people worked in non-financial enterprises in 2017 [GUS 2018], but the scope of enterprises included there in relation to national accounts requires three adjustments:

- Exclusions of microenterprises - data on non-financial enterprises include all entities having the legal form of an enterprise other than entities from agriculture and the financial sector; however, according to national accounts, microenterprises without juridical personality are included in the household sector;

- Exclusions of enterprises included in the general government sector - these are enterprises controlled by the public sector that mostly supply goods on a non-market basis and are financed by taxes and compulsory levies; such enterprises are included in the national accounts as part of the general government sector.

- Inclusion of enterprises operating in section A (agriculture, forestry and fishing).

The number of people working in micro-enterprises without juridical personality is explicitly stated by the Statistics Poland [GUS 2019] and amounts to 3.2 million people, but estimating employment in enterprises classified in the general government sector is much 
more difficult. From the list of government entities published annually by GUS, we selected those that had a legal form of a company (352 entities) and checked employment in those whose name indicated a potentially large scale of activity. Among the largest companies included in the general government were PKP Polskie Linie Kolejowe (40 thousand people) and Przewozy Regionalne ( 7 thousand), as well as a number of hospitals organized as companies (including Bródnowski Hospital, Mazowiecki Wojewódzki Hospital in Siedlce, Ludwig Rydygier Hospital in Kraków, University Hospital in Zielona Góra). In total, we estimate that 0.1 million people worked in non-financial enterprises included in the general government. We estimate the number of people working in enterprises operating in agriculture at 0.1 million (for more on agricultural employment, see the household section). This gives employment in the sector of non-financial enterprises as defined in the national accounts at 6.8 million people.

\subsection{Households}

The second largest sector in terms of value added is the household sector, which in 2017 produced goods and services worth PLN 502.5 billion, to which we add PLN 9.4 billion produced in the non-profit institutions serving households (NPISH). In the context of creating value added, the name of household sector may be misleading, as it mainly covers microenterprises, individual farms, people working on civil law contracts or a significant part of the shadow economy, and does not include value added created by members of households working in other institutional sectors; in the data on the household sector we see their wages but not their value added. In other words, the value added generated by a person working in a large factory will be allocated to the non-financial corporate sector, while their wages will appear in the household sector. In the case of a person working in a micro-business, the value added generated by him/her will be shown in the household sector, as will his/her salary (both on the expenditure side - from the employer's point of view and on the income side - from the employee's point of view).

Since the aim of the analysis is to estimate the value added created by individuals, in the case of households, it is necessary to correct imputed rents and take into account the specificity of agriculture and pensioner households. Since people working in the household sector work on the basis of various legal forms (e.g. employment contracts in microenterprises, self-employment, civil law contracts, the grey economy), it is difficult to obtain a coherent source of data on the number of such people. Therefore, employment in the 
household sector is calculated as the difference between employment in the whole economy and the sum of employment in other sectors.

PLN 59.3 billion of the value added generated in households is allocated to section L (Real estate market activities), where the majority constitutes imputed rents. This is an effect of the structure of the Polish housing market, where the majority of flats are proprietary. The value that the owner derives from living in his/her own dwelling, i.e. imputed rents, is included in the national accounts, which requires correction. First of all, such a service is difficult to assign to a particular person/household - there is no information on where people working in particular institutional sectors live. Secondly, even if it was possible to combine the place of work and the place of residence of a person, the summation of goods produced by that person at work and imputed rent would distort the picture of output in the economy. For example, a retired person living in a city centre in owner-occupied dwelling (high imputed rent and zero market output) could have confusingly attributed higher value added than a person working in an efficient factory, but renting a dwelling (no imputed rent and high market output). As the GUS data do not allow a precise distinction between imputed rents and services provided by micro-enterprises from section $L$, it is omitted in its entirety.

Self-employed farmers constitute a distinctive sub-sector of the household sector. Out of almost PLN 55 billion of the value added generated in the whole section A (agriculture, forestry and fishing), PLN 45 billion falls on households. Private farms generate PLN 36 billion, but around PLN 6 billion can be assigned to imputed rents. Apart from households, the production in section $A$ is also produced in the sector of non-financial enterprises and general governmental, but in their case the importance of agricultural production is marginal - below $1 \%$ of the value added created in these sectors. It should be noted that PLN 15 billion of agricultural production of households is created outside households classified as farmers. Since in national accounts households are classified according to the main source of income, these PLN 15 billion are probably due to households receiving primarily income from paid work or social benefits. A hint may be provided by Eurostat data, which shows that among people working in agriculture, 178 thousand were 60 years old and older, so they could also receive pensions. 
Figure 1. Division of value added generated in Section A (agriculture, forestry, hunting and fishing) among individual institutional sectors

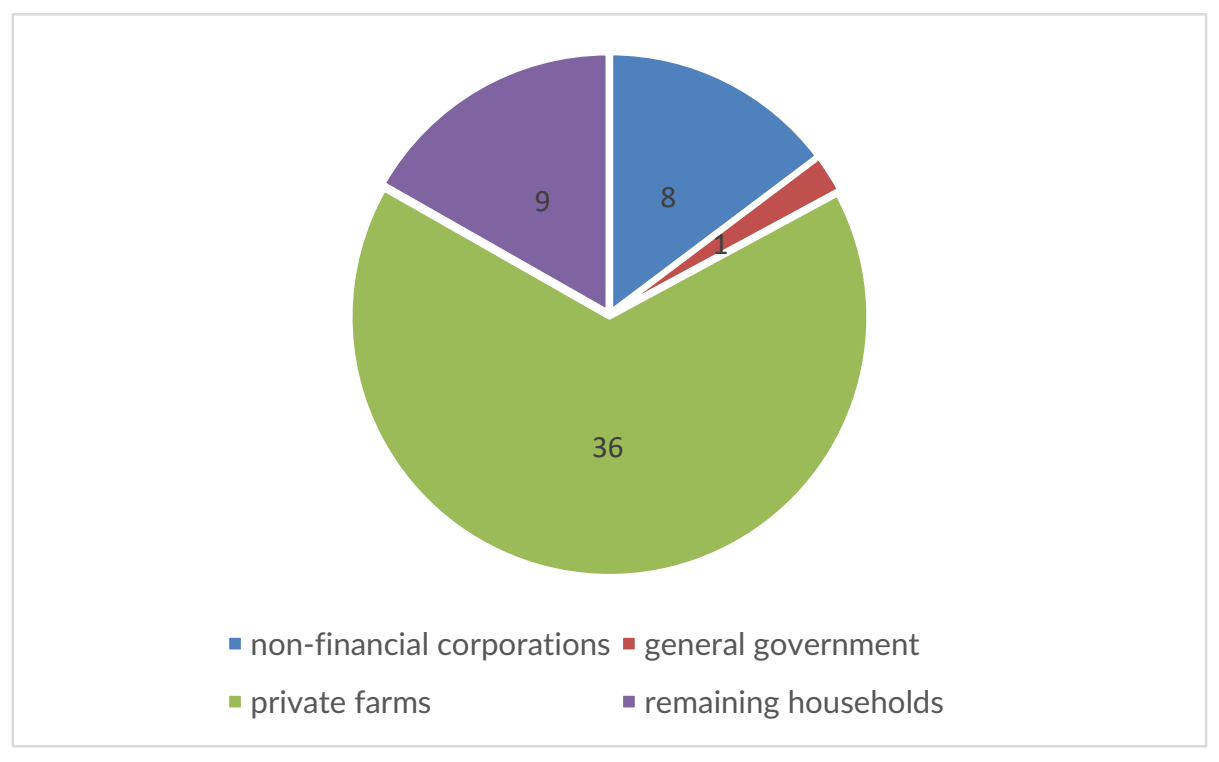

Source: Authors own calculations based on [GUS 2019].

According to national accounts, 1660 thousand people worked in the entire section $A$ in 2017 , the vast majority of whom were individual farms. This is indicated by the statistical yearbook on agriculture, according to which in 2017, 2386 thousand people worked in agriculture, together with helping family members, of which 2262 thousand in private farms. A big difference in the total number of employed between the national accounts and the agricultural statistical yearbook may result from the way the helping family members are included. Nevertheless, it is important that there were only 102 thousand people working on the basis of employment contracts, which shows the scale of employment of people working in section A, which has to be assigned to the sector of enterprises or the general government. In order to maintain consistency with data from national accounts, we assume that there were 1558 thousand people working in individual farms in agriculture, while the remaining 102 thousand worked in other institutional sectors.

In total, 34 billion PLN of value added is assigned to households of pensioners, people living on unearned sources of income and others according to national accounts. An important part of it, even a dozen or so billion PLN, may be imputed rents - a significant part of pensioners live in their own homes. However, in the case of these people, the most important are social transfers, which in 2017 exceeded PLN 205 billion. In further analysis of the tax and contribution burden, we will treat these households separately. However, we will not exclude the value added generated by them from the aggregate of value added 
created in the household sector, as this would also require an appropriate adjustment of the number of employees. Unfortunately, on the basis of the available data, it is difficult to estimate how many people live in households living primarily on pensions, but at the same time earning money by running a micro-enterprise, working in a micro-enterprise, a farm or under a civil law contract. However, this should not lead to material errors, as households of pensioners and persons living on unearned sources accounted for less than $10 \%$ of the value added in the whole households sector.

\subsection{General government}

For the third largest sector, general government, both value added and employment data are directly published by the GUS and Eurostat. In 2017, the value added generated in this sector amounted to PLN 251.2 billion, however, it should be remembered that a significant part of goods produced in this sector does not reach the market, so it is difficult to estimate their value. In national accounts, the value is calculated on the cost basis. In other words, while e.g. the productivity of a person in trade is verified by the market, in the case of a government official it is directly assumed that the value produced by him/her corresponds to his/her salary. According to estimates published by Eurostat, employment in this sector in 2017 amounted to 2805 thousand.

\subsection{Financial enterprises}

The sector of financial enterprises almost fully overlaps with section $K$ of the PKD (financial and insurance activities). About PLN 77.7 billion generated in this section of the PKD is allocated to the financial enterprises sector and the remaining PLN 0.3 billion to the general government. Of the latter, 17 institutions are included in the $\mathrm{K}$-section, the most important of which are BFG, KUKE, Polska Grupa Lotnicza, Towarzystwo Finansowe "Silesia", ARP, PFRON and NFGWiOŚ. According to national accounts, 396 thousand people worked in the entire K-section in 2017. As, apart from the Polish Aviation Group, institutions included in the general government are not large employers, we estimate that out of these 396 thousand people working in the K-section, 386 thousand were in the financial institutions sector, and the remaining 10 thousand in the general government. 


\section{The structure of value added creation in the economy}

The combination of data on individual institutional sectors shows a high concentration of value added creation in Poland. In total, less than 7.2 million people working in the sectors of financial and non-financial enterprises produce almost $60 \%$ of the value added in the Polish economy (excluding imputed rents). As a reference point for this number we assume 24.8 million people aged $20-69$, i.e. a range covering the vast majority of potential employees. According to Eurostat data, in 2017 only 84 thousand people under 20 years of age and 95 thousand people over 70 years of age worked in Poland. Although it is difficult to find comparable data for other countries, based on the statistics of the enterprise sector itself, Łaszek and Trzeciakowski (2018) show that the degree of concentration of value added creation in Poland is higher than in most EU countries. Another worrying observation is still a large number of professionally inactive people. Despite the improvement observed in recent years, the employment rate of people aged 20-69 remained in Poland in 2017 below the EU average (65.4\% vs 66.9\%). For comparison, in Sweden and Estonia, which are the leaders in this respect in the EU and our region, it amounted to $76.6 \%$ and $74.7 \%$ respectively.

Figure 2. Labor productivity and the number of persons employed in individual institutional sectors.

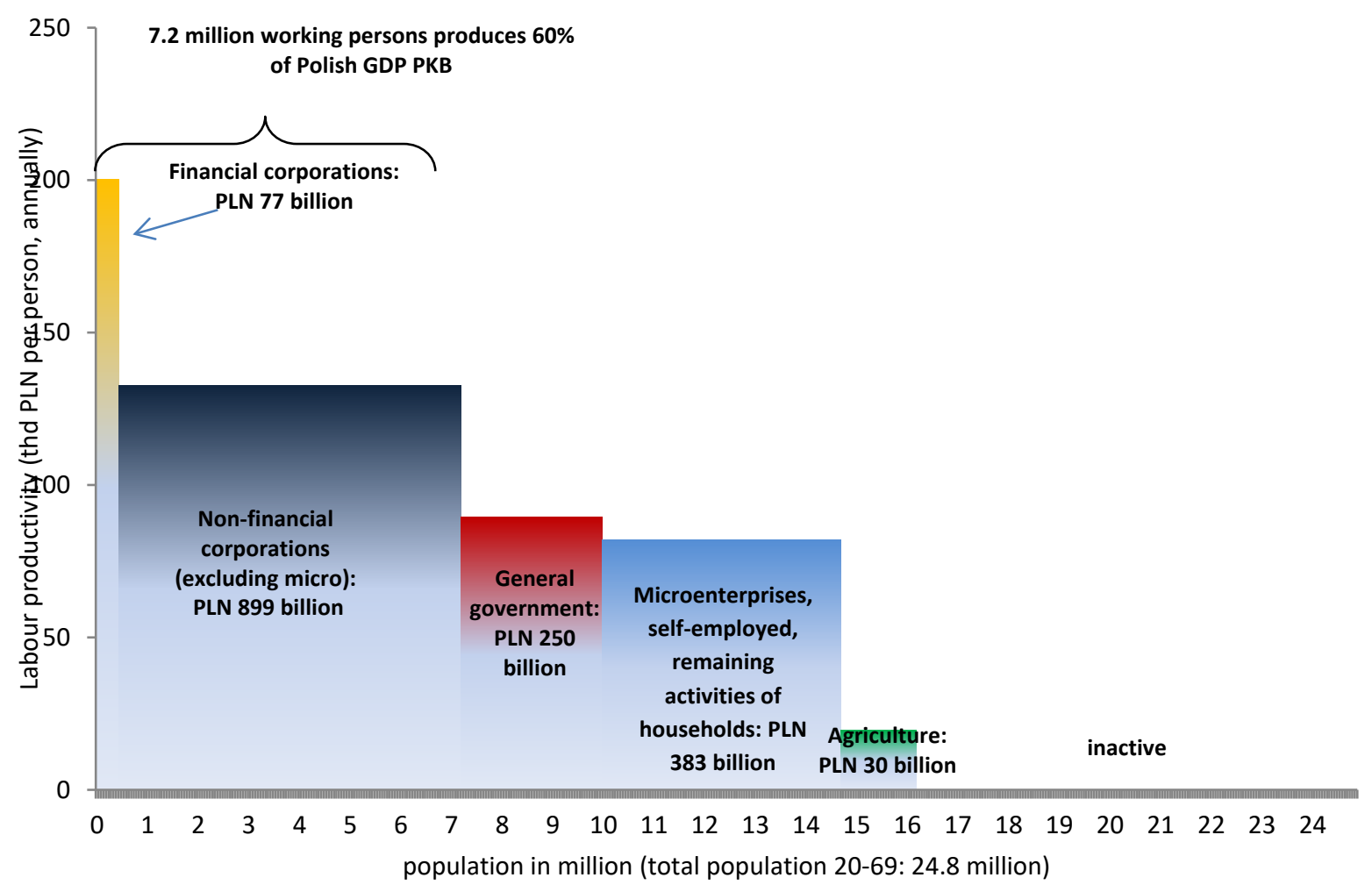

Data does not include imputed rents and employment in section $L$ in the households sector.

Source: Authors own calculations. 
The actual degree of concentration of value added in Poland may be much higher than the aggregated data would suggest. Significant differences in productivity occur not only between sectors, but also within them. Although we do not have access to individual data, based on SBS Eurostat data on value added and employment by PKD and employment, we estimate that in the case of the largest sector of non-financial enterprises, just over $30 \%$ of people working there account for half of production. In the case of agriculture, the concentration may be even greater: in 2015 16\% of people working there accounted for half of production [Łaszek, Trzeciakowski 2018]. A similar productivity disparity can be expected in the household sector. Both within self-employment and microenterprises, as well as civil law contracts, the productivity gap will be very large (highly qualified experts choosing self-employment or civil law contracts for tax reasons vs. inefficient underinvested microenterprises or those earning money in the shadow economy).

Figure 3. Concentration of value added created in the enterprise sector

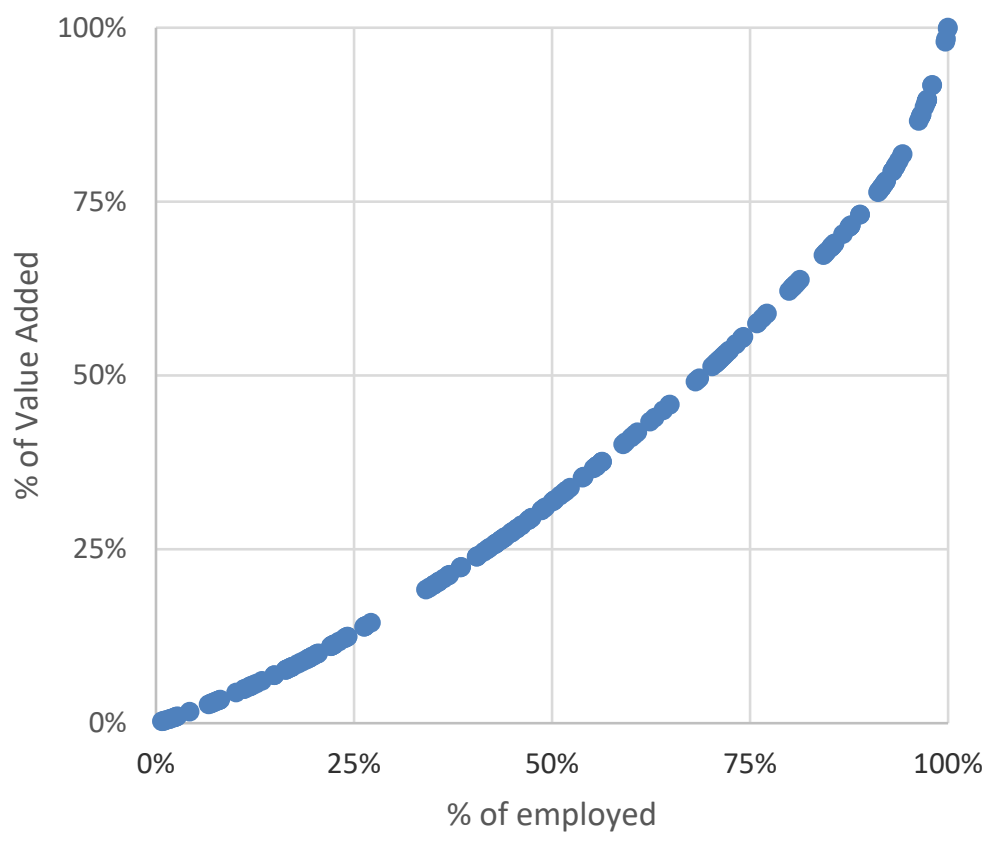

Source: Authors own calculations based on Eurostat SBS data.

\section{Drivers of concentration of value added}

Replication of calculations presented in section 2 for other countries would require indepth analysis of national data sources that goes beyond the scope of this article. Nevertheless, available indicators provided by Eurostat allow to point several features of Polish economy that lead to bigger concentration of value added creation than in majority of other EU countries: 
- Large employment in still low-productive agriculture - in 2017 Poland had the 4th largest share of employment in agriculture in EU, with 10\% working population employed in section A (EU average: 6\%). Furthermore, although in nearly all EU countries labour productivity in agriculture is lower than in remaining parts of the economy, with Hungary being the only exception from that rule, in the case of Poland the gap is among the biggest. While on average in EU labour productivity in agriculture is around $54 \%$ of the labour productivity in the remaining sectors, in Poland it is only $27 \%$.

- Overrepresentation of low-productivity microenterprises - in 2017 in companies employing less than 10 persons in business economy worked nearly $38 \%$ of people employed there. So even putting aside agriculture and public services economy is skewed toward micro-companies, which is worrisome, as labour productivity there is low. In majority of EU countries labour productivity is bigger in larger companies (exceptions are UK, Malta and Luxembourg, most probably due to overrepresentation of highly paid services provided by specialized micro-companies and the self-employed). Still however, on average a person employed in microcompanies in EU produces $58 \%$ of value added per person in larger companies. In Poland the gap between micro-companies and larger firms is much bigger, with labour productivity in micro-companies amounting to just 35\% of larger companies, which is the second worst result in EU - only in Greece this gap is larger. Part of the gap is due to much lower investments made by micro-companies - on average in 2017 PLN 7 thousand per person employed was invested, compared with nearly PLN 25 thousand in larger companies, but also the lack of economies of scale and scope plays a significant role.

- Still large non-standard employment - in 2017 around 6\% of employed declared that their main workplace was either in shadow economy or under so called civil law contracts. Such contracts are less taxed and more flexible than regular employment contracts. Data on employment in shadow economy are indicative and hard to compare between countries, but surveys conducted in Poland and several countries of the region indicate that shadow labour market in Poland is relatively large (Žukauskas 2018). Both employment without contract or on civil law contract dissuades employers from investing in human capital or more advanced physical capital that requires more training leading to dual labour market with part of the employees falling into "less productive" category. Although, on one hand, in recent years with strong demand for labour the non-standard employment of Polish citizens 
has been falling, on the other hand, the employment of foreigners (mainly Ukrainians) has been growing. Polish economy has benefited from the growing supply of labour, but without long term migration policies majority of migrants work on short-term labour permits and contracts. Short term nature of such relationships limits incentives to invest in job-specific skills, thus limiting benefits for both migrants and domestic economy [Trzeciakowski 2018].

- Below average employment rate - despite progress made since the beginning of the century the employment rate in Poland remains below EU average. In 2017 in Poland only 65\% of people aged 20-69 were working, which is the 8th worst result in Poland. Low employment rate is a result mainly of low employment of: women, older workers, people with disabilities and less-skilled people [EC 2019].

Huge differences in labour productivity in Poland compared to other countries raise the question how entities with low productivity stay in business and why labour force does not flow from agriculture, micro-companies and shadow economy to much more productive larger companies. In other words - why productive companies do not grow and increase employment? Analysis of the literature on the growth of companies allows for some hypotheses, concerning rule of law and broadly defined quality of institutions, with particular importance of tax law.

Countries that have better institutional development have larger firms. [Rajan et al. 2001] in their study of 15 Western European countries take efficiency of judicial system as a measure of institutional development and demonstrate that higher level of their development leads to larger size of average company. Similar results are obtained in the studies that focus on particular countries and regional differences in Spain [Fabbri 2010; García-Posada, Mora-Sanguinetti 2015], Mexico [Laeven, Woodruff 2007; Dougherty 2014] and Italy [Giacomelli, Menon 2013, Estrin et al. 2013] approach the problem from another angle focusing not on firm size but on their employment growth aspirations, which are reliable proxies for their actual growth. Their results obtained from the sample of 42 countries indicate that firms are more eager to increase employment in countries where protection of property rights is stronger and corruption smaller.

The literature indicates also that complex and unstable tax can be a biding constrain on company growth law (see e.g. [Friesenbichler et al. 2014]). The high percentage of microenterprises in the countries where tax system has these two features is not only the result of the choice made by entrepreneurs to limit their relations with the tax administration (or to take advantage of the tax preferences often granted to micro-enterprises in such 
systems). It also reflects the lower possibilities of micro-firms to cover the costs of fulfilling their tax obligations (as long as these companies are not covered by tax preferences and operate fully legally). For example, in Canada, New Zealand and the UK, these costs consume $2 \%$ of annual sales in a company with revenues below $\$ 50,000$, but only $0.04 \%$ in companies with sales above $\$ 1$ million [GAO 2011].

The small scale of operations reduces the productivity of companies because it does not allow them to achieve economies of scale, nor to invest in highly productive technologies, whose high costs often require large scale production (see e.g. [Melitz, Ottaviano 2008; Pagano, Schivardi 2003 and Van Biesebroeck 2005]). There are studies showing that small companies have low capacity to invest in ICT [see e.g. Pellegrino, Zingales 2014 and Schivardi, Schmitz 2019]. At the same time, many studies confirm that companies' R\&D investments increase with their size (see e.g. [Baumann, Kritikos, 2016; Di Cintio et al. 2017 and Shefer, Frenkel 2005]).

With a small scale of activity, a tempting alternative to investment (to avoid the associated costs and uncertainty) is to use work from the shadow economy, which has particularly negative effects on growth. Admittedly, it allows micro-enterprises to quickly adapt to changes in the environment that are difficult to predict. These companies can dismiss workers not protected by any contract overnight, reduce their salaries or even fail to pay them, which is possible due to inefficient administration of justice. At the same time, however, they cannot benefit from state power in enforcing claims against unreliable contractors. In addition, due to the risk of both detection and finding an unreliable client, they are practically unable to enter into large or long-term contracts that would guarantee that they would recover at least part of their investment. On the other hand, as their employees are poorly equipped with capital (machinery) and, as a result, are hardly productive, micro-enterprises have difficulty to cover their labour costs, although the evasion of taxes and social contributions mitigates it.

The greater the importance in the economy of those activities that are poorly visible to the tax administration, the greater the risk of an increase in the fiscal burden imposed on other entities. Imposing an additional burden on them is the easiest way to obtain planned fiscal revenues. However, this further weakens the incentives to increase the scale of operations and to invest in productive assets. In the next part of the article we assess how serious the problem is in Poland.

Although in wealthy countries companies are on average larger than in less developed economies (see e.g. [Poschke 2018]), there are also significant differences in the size of 
companies across the former countries. The source of these differences is, in addition to the features of the tax system, the regulatory burden in the product market or labour market. The burden also very often depends on the size of companies (see e.g. [Garicano et al. 2016 and Guner et al. 2008]).

In order to check whether mechanisms described above might explain small percentage of Poles working in larger companies we have gathered information about how Poland scores in several indexes of institutional quality. We have both looked at more general indexes like World Governance Indicators compelled by World Bank or Index of Economic Freedom prepared by Fraser Institute and more focused measures like Product Market Regulation index from OECD or selected measures from World Bank Doing Business. The first group of indexes provide broad overview of institutional quality, but without providing answers about more specific possible bottlenecks. The second group does not provide wider picture, but allow to compare effectiveness of particular solutions in different countries. It should be noted that some of more detailed measures (for example time needed to enforce contracts from World Bank Doing Business) is treated as one of the inputs in broader indexes. Nevertheless, in majority of indexes from both groups Poland scores well below EU average, with particularly poor performance in:

- Economic Freedom - in 2017 Poland was the 3rd worst performing country in EU on this metric, with worse results only in Greece and Slovenia.

- Rule of Law and Voice and Accountability from WGI - in both cases in 2017 Poland ranked 6th from the bottom in EU. In the case of Governance Effectiveness the standing was only marginally better, with Poland ranked 7th.

- Time needed to register business (WB Doing Business) in Poland was the longest in EU; also paying taxes was tiresome (3rd most time consuming in EU) as well as enforcing contracts (7th most time consuming in EU).

Quick look at EU sample confirms results from the mentioned literature - nearly all analysed indexes correlate with the share of employment in larger companies. In other words - in countries with stronger institutions share of employment in companies employing 10 or more persons is larger. The results hold no matter if the employment in $10+$ companies is calculated as percentage of employment in business sector alone or if employment in the whole economy. The strongest correlations are for indexes of Rule of Law, Regulatory Quality, Government Effectiveness and Economic Freedom. From more detailed measures prepared by World Bank time needed to enforce contracts stands out. The only measure that correlates poorly with share of employment is time needed to 
establish company - it turns out that this measure poorly reflects business environment in given country. Taking into account how often this measure is quoted and that it is among easiest to improve among Doing Business metrics, we can speculate that this measure could be compromised by its own success. With heavy media attention on this particular measure it seems plausible that many countries improved business registration process, but without broader reforms.

It should be noted that majority of indexes are correlated. Taking into account their sometimes vague definitions and strong correlation between them at this stage we are not able to assess which particular feature of Polish institutions is the most important factor behind small employment in larger companies. It is worth mentioning however, that great majority of quoted indexes is a stronger predictor of employment in larger companies than GDP per capita. In majority of cases when we run regressions with employment in 10+ companies as dependant variable and subsequent indexes and GDP per capita as independent variable, $p$-values where lower for indexes than for GDP per capita. In other words, quality of institutions might be more important for average size of company than income level of given country.

Table 1. Correlation matrix for the share of employment in companies employing 10 or more people and selected indexes of institutional quality for EU countries. All data for 2017, with the exception of OECD PMR (2018).

\begin{tabular}{|c|c|c|c|c|c|c|c|c|c|c|c|c|c|c|c|}
\hline \multicolumn{15}{|c|}{ Macierz korelacji } & \\
\hline Emp_10 & 1.0 & 0.8 & 0.5 & 0.6 & 0.7 & 0.7 & 0.7 & 0.6 & 0.5 & 0.7 & -0.4 & -0.7 & -0.2 & -0.4 & \\
\hline Emp_ent_10 & 0.8 & 1.0 & 0.5 & 0.6 & 0.6 & 0.6 & 0.5 & 0.3 & 0.4 & 0.7 & -0.3 & -0.7 & -0.2 & -0.4 & \\
\hline GDP_c & 0.5 & 0.5 & 1.0 & 0.7 & 0.7 & 0.6 & 0.6 & 0.5 & 0.7 & 0.4 & 0.2 & -0.3 & -0.1 & -0.5 & \\
\hline WGI_C & 0.6 & 0.6 & 0.7 & 1.0 & 1.0 & 0.9 & 0.9 & 0.5 & 0.9 & 0.5 & -0.2 & -0.5 & -0.3 & -0.6 & 0,5 \\
\hline WGI_RoL & 0.7 & 0.6 & 0.7 & 1.0 & 1.0 & 0.9 & 0.9 & 0.6 & 0.9 & 0.6 & -0.2 & -0.5 & -0.4 & -0.7 & \\
\hline WGI_RQ & 0.7 & 0.6 & 0.6 & 0.9 & 0.9 & 1.0 & 0.9 & 0.5 & 0.9 & 0.7 & -0.3 & -0.6 & -0.3 & -0.6 & \\
\hline WGI_GE & 0.7 & 0.5 & 0.6 & 0.9 & 0.9 & 0.9 & 1.0 & 0.6 & 0.9 & 0.5 & -0.2 & -0.4 & -0.3 & -0.5 & \\
\hline WGI_PS & 0.6 & 0.3 & 0.5 & 0.5 & 0.6 & 0.5 & 0.6 & 1.0 & 0.5 & 0.4 & 0.1 & -0.3 & 0.1 & -0.2 & \\
\hline WGI_A & 0.5 & 0.4 & 0.7 & 0.9 & 0.9 & 0.9 & 0.9 & 0.5 & 1.0 & 0.5 & -0.1 & -0.3 & -0.3 & -0.7 & \\
\hline$F_{-} E F$ & 0.7 & 0.7 & 0.4 & 0.5 & 0.6 & 0.7 & 0.5 & 0.4 & 0.5 & 1.0 & -0.4 & -0.8 & -0.2 & -0.4 & \\
\hline OECD_PMR & -0.4 & -0.3 & 0.2 & -0.2 & -0.2 & -0.3 & -0.2 & 0.1 & -0.1 & -0.4 & 1.0 & 0.2 & 0.3 & 0.0 & $-0,5$ \\
\hline DB_cont & -0.7 & -0.7 & -0.3 & -0.5 & -0.5 & $-0.6 \mid$ & -0.4 & -0.3 & -0.3 & -0.8 & 0.2 & 1.0 & 0.1 & 0.4 & \\
\hline DB_start & -0.2 & -0.2 & -0.1 & -0.3 & -0.4 & -0.3 & -0.3 & 0.1 & -0.3 & -0.2 & 0.3 & 0.1 & 1.0 & 0.4 & \\
\hline DB_taxes & -0.4 & -0.4 & -0.5 & -0.6 & -0.7 & -0.6 & -0.5 & -0.2 & -0.7 & -0.4 & 0.0 & 0.4 & 0.4 & 1.0 & \\
\hline
\end{tabular}


Data from Eurostat:

Emp_10 - employment in firms from business economy employing 10 or more persons as \% of employment in economy; Emp_ent_10 - employment in firms from business economy employing 10 or more persons as \% employment in business economy; GDP_c - GDP per capita in PPS

Data from Worldwide Governance Indicators provided by World Bank, where larger values indicate higher level of development:

WGI_C - Control of Corruption, WGI_RoL - Rule of Law, WGI_RQ - Regulatory Quality, WGI_GE Government Effectiveness, WGI_PS - Political Stability and Absence of Violence/Terrorism, WGI_A Voice and Accountability

$F_{-} E F$ - index of Economic Freedom prepared by Fraser Institute, where larger values indicate more economic freedom

OECD_PMR - product market regulation index prepared by OECD, where lower values indicate less distorting regulations

Data from World Bank Doing Business (all in days):

DB_cont - time needed to enforce contract; DB_start - time needed to register new business; DB_taxes time needed to fill tax declarations for a company

Although correlation is not causation, quoted literature indicate that in this case weaker institutions in Poland might be the main factors behind small share of employment in larger companies. Nevertheless, such hypothesis needs more rigorous testing, with broader choice of control variables and time dimension as well and it will be a subject of our future research.

\section{Structure of tax revenue}

Big differences in the value added generated by individuals are reflected in the wide disparities in tax and social contribution revenue. As in the case of value added, our aim is to allocate the total sum of tax and social contribution burdens to the individual jobs. A part of the taxes (mainly PIT and CIT paid by companies) is reported in the national accounts in such a way that it can be directly attributed to individual workplaces. However, in Poland, the main burden is imposed on labour and has the form of social contributions (mainly ZUS and NFZ) and PIT paid by employees. Its assessment requires additional calculations. This can be well illustrated by the example of a person working in a nonfinancial company, e.g. a factory:

- The value added by the person is assigned to the workplace, i.e. the sector of nonfinancial enterprises, similarly to CIT or PIT paid by this enterprise.

- Social security contributions on the employer's side are shown in the enterprise sector.

- Other workloads - i.e. social contributions on the employee side and PIT and NFZ are allocated to the household sector.

From the point of view of the household sector, salaries paid by all institutional sectors fall into one collective labour remuneration category. In other words, it is not clear in the 
national accounts whether the wage is paid by a non-financial corporate sector or, for example, by the general government sector. Here, however, we can take advantage of the fact that the burden of taxes and contributions on labour contracts in Poland is almost linear. We assign taxes and contributions on the employee side to individual institutional sectors in proportion to the contributions on the employer side.

People working in the non-financial enterprises are the most important source of government revenue. Less than 7 million jobs in this sector brought more than PLN 200 billion to general government in 2017, both in the form of CIT/PIT and other taxes paid directly by companies, as well as taxes and contributions imposed on people working there. There are large differences in effective taxation across institutional sectors. However, when interpreting these differences, a number of reservations should be borne in mind:

- Calculation of effective taxation for pensioners would be difficult to interpret, as their largest income and, consequently, the tax base are the pensions they receive, not the value added by them. Taxation of pensions makes economic sense - first of all, it is consistent with the construction of the entire pension system (if the part of income from which pension contributions are paid is not taxed, then the payment of pensions should be taxed). Secondly, from the point of view of applying an adequate income tax rate, the total income to which pensions should also be included is important.

Table 2. Total burden of income taxes and social contributions

\begin{tabular}{|c|c|c|c|}
\hline & $\begin{array}{l}\text { Value added } \\
\text { (PLN billion) }\end{array}$ & $\begin{array}{l}\text { Total fiscal burden } \\
\text { (PLN billion) }\end{array}$ & $\begin{array}{c}\text { Effective taxation } \\
(\%)\end{array}$ \\
\hline $\begin{array}{l}\text { Economy (excluding imputed } \\
\text { rents) }\end{array}$ & 1687738 & 442678 & $26 \%$ \\
\hline non-financial enterprises & 906567 & 201819 & $22 \%$ \\
\hline financial enterprises & 77319 & 22002 & $28 \%$ \\
\hline $\begin{array}{l}\text { general government } \\
\text { microenterprises, self-employed, } \\
\text { civil contracts and people }\end{array}$ & 251245 & 86766 & $35 \%$ \\
\hline working in the shadow economy & $\begin{array}{c}412905 \\
-\end{array}$ & 70278 & $17 \%$ \\
\hline $\begin{array}{l}\text { individual farmers } \\
\text { pensioners and households living }\end{array}$ & 30275 & 4437 & $15 \%$ \\
\hline on unearned sources & 34586 & 57376 & - \\
\hline
\end{tabular}

Taxes include current taxes on income, wealth, etc., social security contributions and other taxes on production less subsidies on production.

Source: Authors own calculations.

- The taxation and contributions in the case of general government is high due to the specific nature of the services it provides and the resulting value added. The vast majority 
of public sector services are labour-intensive (administration, health care, education), which can be seen in the national accounts. In the general government the wage bill amounts to over $80 \%$ of the value added assigned to that sector. For comparison, in the sector of nonfinancial enterprises it amounts to about 50\%. Since work in Poland is subject to taxes and contributions of about $40 \%$ and capital to taxes of about $20 \%$, the sector with a high share of labour costs will automatically be subject to higher taxes. Moreover, social security contributions also include imputed contributions, i.e., in simplified terms, the state's obligation to pay pensions to groups covered by special pension schemes which currently do not pay contributions (mainly the police and army).

- The low taxation of microenterprises and other entities in the household sector is due to the inclusion of the shadow economy in this sector, which raises the denominator. GUS attributes the shadow economy first and foremost to micro and small enterprises, with the former being classified in the household sector in vast majority. Moreover, in the household sector the value added of people working in the shadow economy outside enterprises is shown.

Figure 4: General government revenue from taxes and social contributions from the private sector (excluding pensioners and public sector employees)
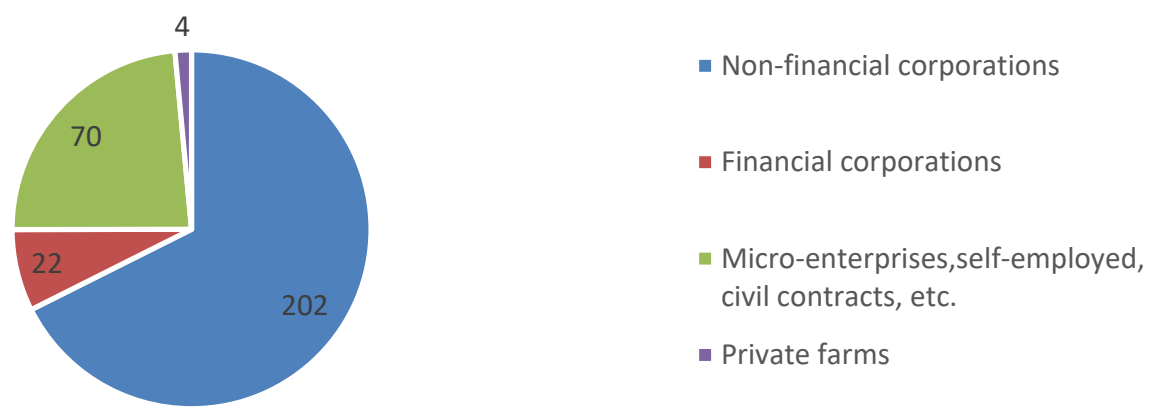

Source: Authors own calculations.

The importance of the non-financial corporate sector is even more evident when considering the structure of tax revenue from the private sector itself. In the case of public sector wages or pensions, only the net payment is really relevant in practice. This is well illustrated by the thought experiment on the possible effects of raising pensions and their taxation by the same amount at the same time: the money physically available to pensioners would not change, but government expenditure and revenue would increase. That's why Figure 4 shows the structure of tax and social contribution revenue from the private sector only. In this respect, the sectors of non-financial and financial enterprises together account for $75 \%$ of the revenues. 
We have only considered so far taxes and social contributions that can be directly linked to specific jobs. In practice, these were taxes on income, social contributions and other taxes related to production less subsidies. We have omitted taxes on products, i.e. primarily VAT and excise tax, which according to the theory are assumed to be ultimately paid by the consumer, although this does not always have to be the case, as shown, e.g. by Bernal (2019) on the data for Poland. However, regardless of whether VAT and excise duties are assigned to consumers or sellers, this will not significantly change the picture. Assuming that these taxes are borne by consumers, the group with the highest income, i.e. employees of non-financial enterprises, will pay the largest proportion of them. The only differences will result from differences in the effective VAT rate between particular groups of employees and the necessity to take into account higher, on average, consumption of micro-business owners than employees. On the other hand, assuming that these taxes are primarily borne by producers, they should be attributed primarily to the sector with the highest production, i.e. non-financial enterprises. In any case, therefore, VAT and excise tax would be allocated primarily to the largest sector in terms of value added, i.e. non-financial enterprises.

\section{Conclusions}

The presented analysis shows a high concentration of value added creation and consequently tax revenue in the Polish economy. Although the sectors of financial and non-financial enterprises employ only 7.2 million people (less than $30 \%$ of population aged 20-69), they are responsible for about $60 \%$ of value added and $75 \%$ of tax and social contribution revenue from the private sector.

Such a structure of the economy constitutes both an opportunity and a threat to the prospects of further growth. The large number of inactive people or those working in low productivity sectors (agriculture, microenterprises, grey economy, etc.) is a potential source of growth. Creating the right conditions for these people to move to more productive sectors of the economy can increase their productivity considerably, to the benefit of themselves and the economy at large. At the same time, however, this structure of the economy may pose a threat related to the temptation to impose additional tax burdens on the most productive sectors of the economy in order to finance transfers to less productive ones. Such policies would risk to consolidate the current structure of the economy. 
The presented results are based on aggregated national accounts and business sector data and are of a descriptive nature, which may provide a starting point for a number of further studies. Firstly, a wider use of disaggregated data, preferably micro-data, would allow the analysis of labour productivity differences not only between individual sectors, but also within sectors. Secondly, simplified international comparison and overview of literature presented in section 3 indicate that such concentration of value creation in Poland might be a result of weak institutions that hamper growth of larger companies. Identification of crucial institutions shaping such results needs a further research. 


\section{References}

Baumann J., Kritikos A.S.: The link between R\&D, innovation and productivity: Are micro firms different?, Research Policy no. 45, 2016.

Bernal, A.: Podatek od wartości dodanej - studium przerzucalności podatku na konsumentów, pracowników i dawców kapitału [The value added tax incidence - tax shifting on consumers, employees and capital owners], Poznań: Wydawnictwo Uniwersytetu Ekonomicznego w Poznaniu, 2019.

Bogumil P.: Securing Poland's economic success II: labour market and product specialization - is there a link?, Ecfin Country Focus no. 4, 2015. Available at: doi:10.2765/157668, accessed: $01^{\text {st }}$ June 2020.

Brzezinski M.: Is high inequality an issue in Poland?, IBS Policy Papers no. 1 (2017), available at: https://ideas.repec.org/p/ibt/ppaper/pp012017.html, accessed: 05

Brzeziński M., et al: Reevaluating Distributional Consequences of the Transition to Market Economy in Poland: New Results from Combined Household Survey and Tax Return Data, IZA Discussion Papers no. 12734, Institute of Labor Economics (IZA), 2019.

Di Cintio M., et al: Firm growth, R\&D expenditures and exports: An empirical analysis of Italian SMEs, Research Policy vol. 46 (4), 2017.

Dougherty S. M.: Legal reform, contract enforcement and firm size in Mexico, Review of International Economics, vol. 22 (4), 2014.

Estrin S., et al: Which institutions encourage entrepreneurial growth aspirations?, Journal of Business Venturing, Elsevier, vol. 28(4), 2013.

Fabbri D.: Law enforcement and firm financing: Theory and evidence, Journal of the European Economic Association, vol. 8(4), 2010.

Friesenbichler K., et al: The efficiency of EU public administration in helping firms grow, Brussels: European Commission, DG Enterprise and Industry, 2014.

GAO, Value added taxes. Potential Lessons for the United States from Other Countries' Experiences, United States Government Accountability Office Report, GAO-11-867T, 2011.

García-Posada M., Mora-Sanguinetti J. S.: Entrepreneurship and Enforcement Institutions: Disaggregated Evidence for Spain, European Journal of Law and Economics no. 40, 2015.

Garicano L., et al: Firm size distortions and the productivity distribution: Evidence from France, American Economic Review, vol. 106 (11), 2016.

Giacomelli S., Menon C.: Firm Size and Judicial Efficiency: Evidence from the Neighbour's Court, Bank of Italy Working Paper no. 898, 2013.

Guner N., et al: Macroeconomic implications of size-dependent policies, Review of Economic Dynamics, vol. 11 (4), 2008.

Laeven, L. i Woodruff, C.: The Quality of the Legal System, Firm Ownership, and Firm Size, Review of Economics and Statistics vol. 89 (4), 2007.

Łaszek A., Trzeciakowski R.: Tylko 5,6 mln osób wytwarza połowę polskiego PKB [Only 5.6 million people produces half of Polish GDP], Analiza FOR (FOR Analysis) no. 8, 2018. Available at: https://for.org.pl/pl/a/6105,analiza-8/2018-tylko-5-6-mln-osob-wytwarza-polowepolskiego-pkb, accessed: $10^{\text {th }}$ April 2020.

Melitz M. J., Ottaviano G. I. P., Market size, trade, and productivity, Review of Economic Studies, vol. 75(1), 2008.

Pagano P., Schivardi F.: Firm size distribution and growth, Scandinavian Journal of Economics, vol. 105 (2), 2003.

Pellegrino B., Zingales L.: Diagnosing the Italian disease, Working Paper no. 23964, Cambridge: National Bureau Of Economic Research, 2017. Available at: https://www.nber.org/papers/w23964, accessed: 29th October 2020.

Poschke M.: The firm size distribution across countries and skill-biased change in entrepreneurial technology, American Economic Journal: Macroeconomics vo. 10 (3), 2018.

Rajan R. G., et al: What Determines Firm Size? CRSP Working Paper no. 496; and USC Finance \& Business Econ. Working Paper no. 01-1. Available at: http://dx.doi.org/10.2139/ssrn.170349, accessed: 31 $1^{\text {st }}$ May 2020.

Schivardi F., Schmitz T.: The IT Revolution and Italy's Two Lost Decades, Journal of the European Economic Association, vol. 18 (5), 2020.

Shefer D., Frenkel A.: R\&D, firm size and innovation: an empirical analysis, Technovation vol. 25(1), 2005. 
Trzeciakowski, R., Potrzebujemy imigrantów. Jak zatrzymać ukraińskich pracowników w Polsce? [We need immigrants. How to keep Ukrainian workers in Poland?), Analiza FOR (FOR Analysis] no. 7, 2018. Available at: https://for.org.pl/pl/a/6100,analiza-7/2018-potrzebujmyimigrantow-jak-zatrzymac-ukrainskich-pracownikow-w-polsce, accessed: 31 ${ }^{\text {st }}$ May 2020.

Van Biesebroeck J.: Firm Size Matters: Growth and Productivity Growth in African Manufacturing, Economic Development and Cultural Change no. 53(3), 2005.

Žukauskas V. (ed.): Shadow Economy: Understanding Drivers, Reducing Incentives, LFMI, 2018. Available at: https://en.llri.lt/news/economic-policy/shadow-economy-understandingdrivers-reducing-incentives//rinka, accessed: $1^{\text {st }}$ June 2020.

Other official documents:

European Commision, Country Report Poland 2019, available at: https://ec.europa.eu/info/sites/info/files/file_import/2019-european-semester-countryreport-poland en.pdf, accessed: $01^{\text {st }}$ June 2020.

GUS, Activity of non-financial enterprises in 2017, Statistics Poland, 2018.

GUS, National accounts by institutional sectors and sub-sectors 2014-2017, Statistics Poland, 2019. 